TEACHER'S STRATEGIES IN TEACHING LISTENING COMRPEHENSION AT SMK BINA BERSAUDARA MEDAN

AN ARTICLE

Submitted in Partial Fulfillment of The Requirements for the Degree of Sarjana Pendidikan

By :

NADIATUL HASANAH

Reg Number : 2163321031

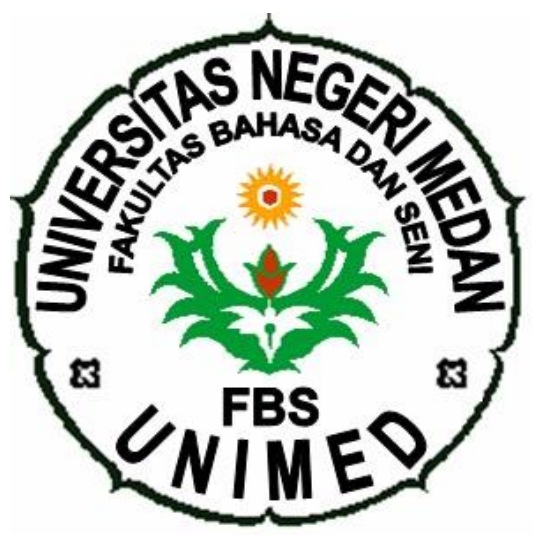

ENGLISH EDUCATION DEPARTMENT

FACULTY OF LANGUAGES AND ARTS

UNIVERSITAS NEGRI MEDAN 
ARTTKFL

Teachers' Strategies in Teaching Listening Comprehension At SMK Bina Bersaudara Medan

Disusun dan Diajukan oleh:

Nadiatul Hasanah

NIM. 216332103

Telah diverifikasi dan dinyatakan memenuhi syarat

untuk diunggah pada jurnal online

Medan, Desember 2020

Menyetujui

Dosen Pembimbing

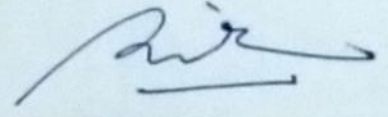

Rika, S.Pd. M.Hum

NIP. 197807172008122001

Ka. Program Studi

Pendidikan Bahasa Inggris

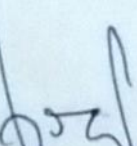

Nora Ronita Duvi, S. Pu, S, S. M. Hum.

NIP.19800522 2008122003 


\title{
TEACHER'S STRATEGIES IN TEACHING LISTENING COMRPEHENSION AT SMK BINA BERSAUDARA MEDAN
}

*Nadiatul Hasanah

**Rika

\begin{abstract}
Hasanah, Nadiatul. Registration Number: 2163321031. Teacher's Teaching Strategies In Teaching Listening Comprehension At SMK Bina Bersaudara Medan. English Educational Program, Universitas Negeri Medan, 2020
\end{abstract}

This study aims to find out the teaching strategies implemented by teacher in teaching listening comprehension at SMK Bina Bersaudara Medan. The research was conducted by descriptive qualitative research through two phases: observing and interviewing. It was conducted in SMK Bina Bersaudara Medan at the XI grade class. The instruments of the research were: field notes and interview transcripts. The results of this research were first, there were only two strategies that applied by the teacher in teaching listening comprehension those are Metacognitive Strategies and Cognitive Strategies. The second was the underlying factor of using those kinds of strategies in teaching listening comprehension namely the effectiveness of teachers in teaching, basically a teacher should be a good communicator, should teach the students effectively and many more which makes a teacher become professional and the most important part is the instruction strategies which she chooses to deliver the materials which helps students in learning more effective.

Key words :Teacher's Strategies, Listening Comprehension, Teaching Listening

\footnotetext{
*Graduate Status

** Lecturer Status
} 


\section{INTRODUCTION}

\section{Background of Study}

Listening is the ability to identify and understand what others are saying. This involves understanding a speaker's accent or pronunciation, his grammar and his vocabulary, and grasping his meaning (Howatt and Dakin 1974). Learning listening will help us to improve speaking skill considerably. People need to hear various types of English repeatedly and continuously if they want to communicate properly, meaningful, and naturally. It means that without hearing people cannot acquire language because listening provides language input

Teaching listening needs more attention in order to develop students' language. In some cases of the language classroom, listening is considered to be the most difficult language skill for students because it needs more attention and concentration to comprehend the material that included understanding dialogue and monologue text. In addition, according to Heaton (1984:64) teacher should conduct an appropriate and suitable strategy for developing and enhancing students' listening skill and motivate them as well, so that they will achieve the goals in listening comprehension. According to O'Malley \& Chamot, three major types of strategies are distinguished in accordance with the informationprocessing model; cognitive strategies, meta-cognitive strategies and social/affective strategies.

In fact there are some problems found at eleventh grade of SMK Bina Bersaudara in the context of the teaching and learning in listening, especially at eleventh grade. For example, the listening skill in the classroom is seldomly conducted there, it's only conducted in two or three times in a month. It made the students become unfamiliar with the listening itself and also unfamiliar with listening to the English native speaker. To overcome those problems, it is important for the teacher at SMK Bina Bersaudara to applies strategies in teaching listening to help the students to be more interested and active in the learning process. 


\section{REVIEW OF LITERATURE}

1. Listening Comprehension

Listening is the ability to identify and understand what others are saying. This involves understanding a speaker's accent or pronunciation, his grammar and his vocabulary, and grasping his meaning (Howatt and Dakin). Listening comprehension is one of the most important skills to communicate. It is necessary to learn and apply listening strategies that contribute to acquire a foreign language. The use of listening strategies can help students to develop their listening comprehension skills, the teachers carry a big responsibility in this process either in or out of the classroom. Teachers have a huge impact on their students, either positive or negative, and it is the teacher's responsibility to create a friendly atmosphere to make the listening activities successful.

\section{Teaching Listening Comprehension}

Brown (2000:7) defines "teaching as showing or helping someone to learn how to do something, giving instructions, guiding in the study of something, providing with knowledge, causing to know or to understand".

In order to help students improve their listening ability, teachers have to understand and mastered the teaching listening comprehension strategies which one of the steps is explain and instruct effective listening strategies to comprehend spoken texts, and to help students solve their listening difficulties.

\section{Teaching Strategies in Teaching Listening Comprehension}

Strategies can be taught of as the ways in which a learner approaches and manages a task, and listeners can be taught effective ways of approaching and managing their listening. These activities seek to involve listeners actively in the process of listening (Jack, C, Richard 2008:11). As Buck (2001:104) identifies two kinds of strategies in listening such as Metacognitive and Cognitive Strategies, but also there is another strategies which is Social strategies, sometimes referred to as socio cultural strategies (Savignon \& Sysoyev, 2002), “ the teacher help or direct the students work with others and understand the target culture as well as the language" (Oxford, 2003: 14). 


\section{RESEARCH METHODOLOGY}

The research design in this study was conducted descriptive qualitative research. Creswell (1994: 171) stated that descriptive method is collecting the qualitative data, analyzing data, and writing result. Based on definition above, descriptive method is a method to collect and analyze data, and draw conclusion of analyzed data.

\section{Source of Data}

Qualitative method more typically use non random or purposive selection techniques based on particular criteria (Ary, 2006:450). It means that researcher cannot take the teachers randomly as research subject in order to get data which is suitable with this research. Researcher has her own qualification for choosing the data and sources of data which is the one who related and know how to answer the problem which has been formulated. Data of this study was an English teacher at the eleventh grade of SMK Bina Bersaudara chosen as a subject to be participated in this research.

\section{The Techniques and Instruments of Data Collection}

The instruments of the research was field notes form the observation and the interview transcript. Therefore, the researcher applies the following steps: Here, the researcher used fields notes in observation to collect the data. The researcher observes the situation and condition in class of teaching and learning activity, the audio visual, laboratorium, and the speaker as the facilities, and the teacher student's interaction. The Arikunto (2006:155) says that interview also called as the dialogue did by the interviewer and interviewee. 


\section{The Techniques of Data Analysis}

The concept of data analysis is a process of systematically searching and arranging the interview transcript, field notes and other materials that a writer accumulate to increase her/his understanding and to enable her/him to present what she/he has discovered to others (Bogdan \& Biklen, 2007:30). The data of this research was the transcription from observation, field notes, interview and documentation. The data from the observation and field notes used to answer the first problem on this research while the data gotten from the interview and documentation used to answer the second problem. The transcriptions of observation analyzed by using interactive model. Miles, Huberman, and Saldana (2014:130) asserted that interactive model consisted of three current flows of activities. They are;

(a) Data condensation (the observation of teachers and students during the classroom teaching process, and transcript of interview),

(b) Data display (the process of organizing the data; the data display of this study). The data belonging to the teacher's behavior in the process of teaching listening comprehension, and

(c) Conclusion drawing(verify the process of teaching listening comprehension, and conclude the process). 


\section{FINDINGS}

1. Strategies Applied in The Classroom

After the researcher observed there are only two teaching listening strategies mostly applied by the teacher they were metacognitive and cognitive strategies.

\section{Data 1}

A: During your teaching activities, what kinds of your strategies do you use in teaching listening comprehension mam, are they the same strategies as we discussed before?

$\boldsymbol{B}:$ As we discussed before yes I know the three strategies, also the step by step of strategies I mostly used is done. Sometimes, I am using metacognitive, and cognitive but I never use socio affective strategies.

In data 1 showed that the teacher familiar to those three kinds of

strategies and she used metacognitive strategies to teach listening comprehension in class. In teaching learning process metacognitive strategies are those used to manage, plan and evaluate the use of cognitive strategy, the other hand it has to be related each other. In 1990, Oxford made a diagram of metacognitive strategy system. In this system, there are three parts, centering learning, arranging and planning and evaluating, in metacognitive strategy. The statement above is quite related to the result observation and also the answer of the teacher down below.

\section{Data 2}

A: Do you apply some steps for preparing a class mam?

B: Yes, I always prepare everything in teaching and learning activities, the strategies used, the topic and some entertainment, second select, third monitor, fourth pay attention, and then understanding the material based on the information and the background knowledge 
The statement of the teacher showed that she used the metacognitive first and followed by the cognitive strategies then ended it with metacognitive. And it is related to the researcher's observation that before the teacher got into the class, she prepared things that she would be need while teaching listening comprehension and she seemed ready to teach because all the steps of teaching listening comprehension were done smoothly as she planned and arranged everything.

Table 4.1 Teacher's Strategies Implemented in Classroom

\begin{tabular}{|c|c|}
\hline Teacher's Strategies & \% \\
\hline Metacognitive Strategies & $55 \%$ \\
\hline Cognitive Strategies & $45 \%$ \\
\hline Total & $100 \%$ \\
\hline
\end{tabular}

It can be seen from the table how often the teacher used strategies in teaching listening comprehension, as written in the table the metacognitive strategies and cognitive strategies are balanced which mean the teacher implemented both of those strategies in every listening comprehension activities. This factual data is come from the result observation the teacher certainly used the metacognitive strategies and followed by the cognitive strategies. However the socio affective strategies have never been implemented by the teacher yet, it might be a chance for the teacher to try that kind of strategies but in any circumstances which can be said she rarely use it while teaching listening comprehension. 
2. Teacher's Reason in Applying Those Strategies in Teaching Listening Comprehension

After analyzing the strategies used by the teacher, the researcher wanted to know what is the reason in applying those strategies in the teaching listening comprehension activities.

\section{Data 3}

A: What are the underlying factors of using strategies in teaching listening comprehension mam?

$\boldsymbol{B}$ : I want to make my class run smoothly, I think that is the hope of every teachers, but it does not make the students felt bored or frustrated that they only listen to the audio all the times during the class.

It shows that the teacher has some efforts to teach listening skill, like when she taught the students how to have a good listening skill by using strategies it made the students realized that when they have listening activities it would be easier for them when they apply some strategies.

It is related to the statements of Jalbani (2014) there are more key elements which help the teachers personally and professionally and also their students. These are being reflective, empathizing when required, respect students, a good communicator, her/his own love of learning and many more which makes a teacher effective and the most important part is the instruction strategy which he/she chooses to deliver content which helps students in learning more effectively. 


\section{DISCUSSION}

From the data interpretation and analysis, the researcher found out that there were only two strategies that applied by the teacher in teaching listening comprehension, which are metacognitive strategies and cognitive strategies.

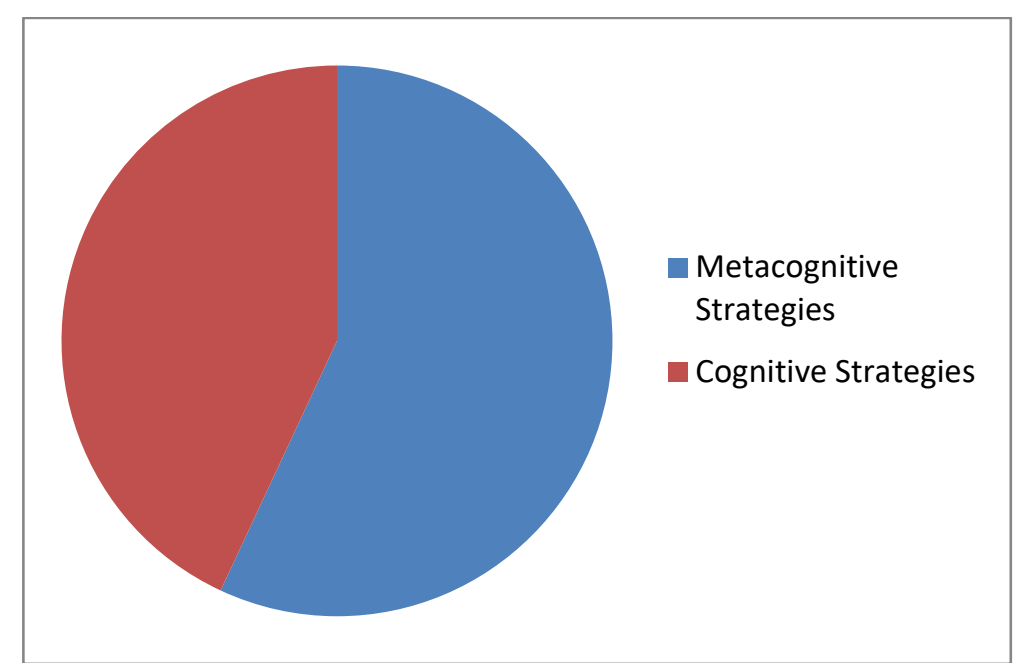

Figure 4.1 Teacher's Strategies Implemented in Classroom

Based on the figure above it showed that metacognitive strategies about $55 \%$ applied in the classroom it is related to the statement from the data 1 that teacher used metacognitive strategies even before the meeting held, $45 \%$ cognitive strategies the teacher said that sometimes when the topic or background has been clearly showed in the textbook she didn't have to explain or elicit the students about what they will hear or learn. It means that the teacher prepared and did the process mostly using metacognitive strategies followed by the cognitive strategies and the teacher used these strategies repeatedly while teaching listening comprehension. 
After interviewing and observing the teacher the researcher found out that there was a reason as the factor of applying those strategies in teaching listening comprehension, namely the effectiveness of teachers in teaching, basically a teacher should be a good communicator, should teach the students effectively and many more which makes a teacher become professional and the most important part is the instruction strategies which she chooses to deliver the materials which helps students in learning more effective.

It means that the teacher always want to have an effective teaching and learning activities especially in teaching listening comprehension, then support the students to have some motivations in learning listening comprehension by demonstrating these kinds of strategies and make them interest and easily do every task that instructed by teacher.

This study was dealing with the study of (Jack, C, Richard 2008:11). Jack, C, Richard states clearly that the three strategies can be taught in teaching listening comprehension. Which are: Metaconitive Strategies are higher order executive skills that may entail planning for, monitoring, or evaluating the success of learning activities (Brown et al., 1983).

These experts' statements quite related to the result observation where the teacher led the class the teacher clearly planned the topic before entering the class, then she monitored the improvements of her students in listening skill such as; their vocabulary, grammar, and so on. Then she evaluated the students in written evaluation by instructed them to submit the task that they have done. 
Cognitive Strategies are those that we use in order to complete an immediate task. For example, when the teacher gives a clue related to the audio a student may find out about the topic before listening, in order to predict content (Arnold, 1999).

In the result observation the teacher elicit the students to make them know what they will learn by asking them the background knowledge which related to the listening topic, so when they hear the audio they will not confuse about context of the conversation.

Socio Affective Strategies Socio-affective strategies involve communicating with teachers, classmates, and native speakers, as well as developing self-confidence and motivation, it can be conclude that SocioAffective strategies are concerned with the learners' interaction with other speakers and their attitude towards learning. For example, the teacher instruct them to have a telephone conversation with another student in order to develop confidence. Thus for this kind of strategy the teacher said that she rarely or can we say it never use it she was only focus to the metacognitive and cognitive strategies. 


\section{CONCLUSION}

1. There are two strategies that implemented by the teacher in teaching listening comprehension at SMK Bina Bersaudara Medan which are metacognitive strategies and cognitive strategies were applied step by step. Based on the figure 4.1 it mentioned that $55 \%$ metacognitive strategies applied it means that the teacher applied them a bit more then cognitive strategies with just $45 \%$ applied in teaching listening comprehension.

2. Teacher's reason in applying those strategies in teaching listening comprehension which is the effectiveness of teachers in teaching, basically a teacher should be a good communicator, should be teach the students effectively and many more which makes a teacher effective and the most important part is the instruction strategy which she chooses to deliver material which helps students in learning more effectively. 


\section{REFERENCES}

Anderson, A. \& Lynch, T. (1998).Listening. New York: Oxford University Press.

Brown, G., 1995. Dimensions of difficulty in listening comprehension. In: Mendelsohn, D., Rubin, J. (Eds.), A Guide for the Teaching of Second Language Listening. Dominie Press, San Diego, CA,pp. And Brown, H.D. 2000.Principle of Language Learning and Teaching. San Francisco: San Francisco University.

Creswell, J (2014). Research Design Qualitative, Quantitative and Mixed Method Approach. Boston: Pearson Education.

Eysenck, M.W., Keane, M.T., 1995. Cognitive Psychology, 3rd Edition. Psychology Press, Sussex.

Flavell, J.H., 1979. Metacognition and cognitive monitoring: a new area of cognitive-developmental inquiry. American Psychologist 34 (10), 906-911.

Harmer, J (2007).How To Teach English.Second Edition.Cina: ISBN.

Guan, Y 2015) A Literature Review: Current Issue in Listening Strategy Research and Instruction on ESL Adult Studentss'. International Journal of teaching, education and language Learning IJTELL). Vol.2 No.1 ISSN: 2373-7921

Jannatun, Act (2013) Teachers' Strategy In Teaching listening comprehension \{thesis) Indonesia University of Education (Upi).

Richard, Jack, C. S.(2010). Teaching Listening and Speaking From Theory to Practice.Cambridge University Press.United Stated of America.

Vandergrift, L. 2006. Second Language Listening: Ability or Language Proficiency?The Modern Language Journal 90, 6-18. And Vandergrift, L. (1999). Facilitating second language listening comprehension: acquiring successful strategies. ELT Journal, 53(3),168-1 